\title{
Is there any link between accreditation programs and the models of organizational excellence?
}

\author{
Existe uma relação entre os programas de acreditação e \\ os modelos de excelência organizacional? \\ ¿Existe una relación entre los programas de acreditación y \\ los modelos de excelencia organizacional?
}

Fernando Tobal Berssaneti ${ }^{1}$, Ana Maria Saut ${ }^{2}$, Májida Farid Barakat ${ }^{3}$, Felipe Araujo Calarge ${ }^{3}$

How to cite this article:

Berssaneti FT, Saut AM, Barakat MF, Calarge FA. Is there any link between accreditation programs and the models of organizational excellence? Rev Esc Enferm USP. 2016;50(4):648-655. DOI: http://dx.doi.org/10.1590/S0080-623420160000500016

${ }^{1}$ Universidade de São Paulo, Escola Politécnica, São Paulo, São Paulo, Brazil.

${ }^{2}$ Universidade de São Paulo, Escola Politécnica, Programa de Pós-Graduação em Engenharia de Produção, São Paulo, São Paulo, Brazil.

${ }^{3}$ Universidade Nove de Julho, Programa de Pós-Graduação em Engenharia de Produção, São Paulo, São Paulo, Brazil.

\begin{abstract}
Objective: To evaluate whether accredited health organizations perform better management practices than non-accredited ones. Method: The study was developed in two stages: a literature review, and a study of multiple cases in 12 healthcare organizations in the state of São Paulo, Brazil. It surveyed articles comparing hospital accreditation with the EFQM (European Foundation for Quality Management) model of excellence in management. According to the pertinent literature, the accreditation model and the EFQM model are convergent and supplementary in some aspects. Results: With $99 \%$ confidence, one can say that there is evidence that accredited organizations scored better in the evaluation based on the EFQM model in comparison to non-accredited organizations. This result was also confirmed in the comparison of results between the categories Facilitators and Results in the EFQM model. Conclusion: There is convergence between the accreditation model and the EFQM excellence model, suggesting that accreditation helps the healthcare sector to implement the best management practices already used by other business sectors.
\end{abstract}

\section{DESCRIPTORS}

Accreditation; Hospitals; Hospital Administration; Quality Management; Health Evaluation.

\section{Corresponding author:}

Ana Maria Saut

Depto. de Engenharia de Produção, Escola

Politécnica da Universidade de São Paulo

Av. Prof. Almeida Prado, Trav. 2, 128

CEP 05508-900 - São Paulo, SP, Brasil

ana.saut@usp.br
Received: 12/15/2015

Approved: 06/02/2016 


\section{INTRODUCTION}

The need to implement quality control and management standards in healthcare services has significantly increased in the last decades, and has become an important aspect of organizations working in this segment. Organizations have faced increasing demands in terms of compliance with existing laws, proper cost management, and the satisfaction of the services' users.

Healthcare organizations can use a wide range of quality programs, such as: structured method to improve processes (PDCA, 8D, 5S, 3R); accreditation (ONA, JCI, CCHSA, NIAHO); organizational excellence models (PNGS, the Malcolm Baldrige National Quality Award, the European Foundation for Quality Management [EFQM]); and the International Organization for Standardization (ISO) rules (ISO 9001:2008; ISO 14000; ISO 26000), among others.

An external quality mechanism can be defined as a regional or national process voluntarily created by services providing organizations to improve the organization and delivery of health care considering standards developed by teams moderated by a non-partisan authority involving users, providers, purchasers, and government ${ }^{(1)}$.

Today Brazil has no mandatory program for hospital services quality evaluation; however, governmental authorities have discussed the possibility of adding an article providing for mandatory evaluation and certification of services quality to the Healthcare Organic Law ${ }^{(2)}$. The bill does not define the evaluation process to be adopted, but assumes the existence of a quality system involving the adoption of standards for operational procedures, technical quality, and management and humanized service ${ }^{(3)}$.

The acceptance and success of hospital accreditation programs, either at the global or local level, is closely related to the social, political, and economic environments that define incentives and disincentives for implementation ${ }^{(1)}$. A study comprising managers of accredited Brazilian hospitals showed that the implementation of quality systems aimed at accreditation is made at the initiative of each hospital, and there is no incentive (financial or of any other nature) to obtain accreditation ${ }^{(4)}$.

However, it is worth mentioning that quality management in organizations that provide healthcare and their strategic objectives depend not only on their social context, but also on actions and resources related to the population's healthcare that depend on governmental spheres at the municipal, regional, national, international, and global levels ${ }^{(5)}$.

In terms of the structuring of quality management evaluation systems in organizations that provide healthcare services in Brazil, there is a tendency towards accreditation ${ }^{(4)}$.

Generally speaking, the literature examines the focuses of accreditation and organizational excellence, individualizing each concept. Few studies propose comparative evaluation between accreditation concepts and standards and the organizational excellence models ${ }^{(6-7)}$, as well as the result of evaluations performed in both $\operatorname{models}^{(8)}$. In addition, there is a research gap regarding the benefits of accreditation programs $s^{(9-10)}$.

Consequently, the main objective of this article is to evaluate whether organizations with national and/or international accreditation present better management practices and better results than non-accredited organizations.

\section{METHOD}

In light of the research method proposed to meet the objective of this survey, a hybrid approach structured in two stages was employed. In the first phase, literature was reviewed to identify articles comparing both quality management focuses (accreditation and the management excellence model). The second stage aimed to evaluate the managerial practices used, as well as results achieved by accredited and non-accredited organizations. It applied the self-evaluation questionnaire of the EFQM model to multiple cases through structured interviews with managers, board representatives, or officers in charge of the quality management system in the healthcare organizations surveyed.

The EFQM is considered to be one of the main excellence models used for quality evaluations in hospital institutions because it evaluates workers' satisfaction in terms of perception - including motivation - feeling of belonging, communication, personal relationships, training, career development, equality of opportunities, health, and security ${ }^{(11)}$. Moreover, the EFQM model follows a global tendency where increased productivity and efficiency result from human capital ${ }^{(11-14)}$. Finally, the EFQM excellence model was selected because it has already been used by hospitals ${ }^{(13,15)}$ and because it provides a common language and understanding between hospital managers and evaluators ${ }^{(13)}$.

\section{Article Selection}

The bibliographic survey considered three electronic databases (MEDLINE, Web of Science, and the Portal de Busca Integrada of the Universidade de São Paulo) defined according to the relevance of the topic surveyed. The research was performed in September 2015.

Databases were consulted with no research area or publication date restrictions, considering peer-reviewed articles published in journals. The keywords were "accreditation", "EFQM", "quality," and "health." The first survey generated a database with 122 articles and, after excluding duplicate articles, 87 articles were selected.

A reading of headings and abstracts was the selection criterion. To be included in the database, articles should contain one or more aspects of both quality programs: "accreditation" and "EFQM." In addition, the database included only articles with integral text available in English or Portuguese. Altogether, 13 articles were selected and transferred to the Mendeley@ software of bibliographic references, version 1.14 . 


\section{Analysis of Articles for Reference}

This study matches a quantitative analysis of the literature, many times known as Bibliometrics ${ }^{(16)}$. The Web of Science search base provides a set of metadata essential to bibliometrics analysis, including a summary, references, and a number of citations, among others.

The final result of this bibliometrics procedure was the selection of 10 articles with full citations available to establish the metadata file, and further analysis of the citation network that is based on the assumption that authors referred to documents considered important to the research. The citation network allows the identification of the most-cited references in the articles that comprise the initial database. This study applied a filter to identify references quoted by at least three articles in the database.

Data were extracted using the Sitkis software version $6.1^{(17)}$, while the network diagram was prepared using the Ucinet 6 for Windows ${ }^{\circledR}$ software, version 6,535 ${ }^{(18)}$.

Three articles were identified in the reference articles network $^{(19-21)}$. However, only two articles ${ }^{(20,21)}$ met the selection criteria of this study and, thus, were considered eligible for analysis. After analyzing the citations network, the final article database considered for content analysis comprised 15 articles ${ }^{(1,5-8,11,20-28)}$.

Among the research areas proposed by the Web of Science, the main ones found in the eligible articles $\mathrm{da}^{-}$ tabase were "health care sciences service" and "health policy services.”

\section{Study of Multiple Cases}

Data were collected by teams comprised of engineering production undergraduate students from a public university of São Paulo. The work proposed by the research intended to discover how the Quality Management System (QMS) of an organization is organized and structured. During classes, through expository lectures, students were familiarized with the EFQM Excellence model and with the self-evaluation questionnaire, qualifying and training them to apply the questionnaire. Visits were scheduled with the person responsible for the Quality Management System of the selected institutions that had already agreed to participate in the research projects approved by the Research Ethics Committee of the Faculdade de Medicina at the Universidade de São Paulo (FMUSP) - CAAE 50035315.1.0000.0065, report 1.294.121.

During onsite visits by the team to learn about QMS structure, some documents were consulted, such as: the quality handbook; process flowcharts; working procedures and instructions; and non-conformity reports, among others. In addition, it gathered general information about the investigated organizations from their internet websites, such as whether it was a public or private institution; accredited (or not); how long it had been accredited; and type of accreditation, among other pertinent information.

Teams collected data using the questionnaire based on the $\mathrm{EFQM}^{(29)}$ model structured into 120 questions, grouped according to nine criteria, namely: Leadership; Policy and Strategies; People; Partnerships and Resources; Processes; Customer Results; People Results; Society Results; and Key Results for Performance. These questions were weighted and evaluated using a five-level Likert scale (1 - no advance; 2 small advances; 3 - some advance; 4 - significant advance; 5 - objective achieved). There was also the option of responding "have no opinion/do not know (Ns/Nc)," following the observation that a similar methodological procedure had been applied to health-related studies ${ }^{(30,31)}$.

By the end of the study, each team delivered a report with data collected in each participating hospital and, by the end of the academic semester, respondents were invited to watch the final presentation of the groups.

The results of the EFQM quality self-evaluation versus the health organization accreditation status (accredited or non-accredited) were considered in order to compare both focuses. Following were the hypotheses tested: H01: The mean scoring of the FACILITATORS criteria of the accredited health organization is higher than that of the non-accredited ones. H02: The mean scoring of the criteria of RESULTS of the accredited health organization is higher than that of the non-accredited ones. H03: The TOTAL mean scoring of the accredited health organization is higher than that of the non-accredited ones.

Results were evaluated using the Student's t-test to compare two means, with non-paired data (i.e., non-correlated populations) for populations' standard deviations unknown but considered to be equal ${ }^{(32)}$. The assumption of equal population deviations was previously validated by the Levene's test, with evidence of deviation equality between "accredited" and "non-accredited" groups in the three categories evaluated (Facilitators, Results, and Total Score). Results were analyzed using the Minitab ${ }^{\circledR}$ statistical software, version $17.1 .0^{(33)}$ with a confidence level of $99 \%$.

\section{RESULTS}

\section{Brief Contextualization of Accreditation Focuses and Organizational Excellence Models}

Regarding the accreditation process, it is a procedure of third-party or external evaluation of the organization's quality management system with the main characteristics based on: adoption of rules; peer reviews; and administration by independent organization to foster organizational development based on the business plan's reliability ${ }^{(28)}$. Many countries have accreditation programs, and the Joint Commission International (JCI) program is a milestone in global accreditation, being referred to since $1987^{(34)}$ as the oldest accreditation program.

Brazil has its own accreditation program known as the National Accreditation Organization (Organização Nacional de Acreditação [ONA]). Today, less than 5\% of hospitals have some kind of accreditation, and most of these are accredited by the ONA national program, despite other international accreditations in Brazilian 
health organizations such as: JCI; the Canadian Council on Healthcare Services Accreditation (CCHSA); and National Integrated Accreditation for Healthcare Organizations (NIAHO).

Awards for performance excellence and respective organizational excellence models started with the Deming Prize in 1950 in Japan, followed by the Malcolm Baldrige National Quality Award (MBNQA), and the EFQM in the 1980s. Today, awards for performance excellence based on MBNQA or EFQM gave rise to management prizes and models in many countries ${ }^{(28)}$.

The European Foundation for Quality Management model, known as EFQM, was founded in 1988 by the CEOs of 14 European corporations. It is defined as a holistic structure applicable to any organization, regardless of its size or sector. It was used for the first time to support the evaluation of organizations for the 1992 European Quality Prize, and has been revised over the last decades. The main objective is to increase organizations' competitiveness. In addition, it can be used as a self-evaluation instrument as well as an auditing instrument for the Quality Award ${ }^{(25)}$.

In the 2000s several researchers studied the most popular quality models in Europe at that time. Quality models do not compete with each other; rather the accreditation, visitation, EFQM, and ISO models overlap ${ }^{(22)}$. The EFQM model is the most flexible and comprehensive, and represents the strategic and general aspects, and well as the results, of quality management. Accreditation is more directly related to healthcare and is considered to be a more specific, administrative, and prescriptive model. The EFQM provides a supplementary perspective that could help in expanding the scope of quality of managerial functions in healthcare organizations. Researchers have observed these models' viability of convergence.

A study concluded that organizational accreditation models such as the JCI provide a structure for converging and integrating the strengths of all models (ISO, EFQM, and visitation) in a consensual healthcare quality evaluation model ${ }^{(23)}$.

In conceptual terms the EFQM was considered to be the most comprehensive model for an organization to meet quality management goals ${ }^{(24)}$. However, the models' scope and perspectives overlap. The ISO perspective can be fully incorporated into either accreditation or the EFQM. Visitation and accreditation are closer to the actual delivery of healthcare, while the ISO and EFQM mainly approach managerial and organizational conditions wherein care processes are performed. The models seem to be supplementary and nonexclusive.

Studies highlight that EFQM and accreditation models have different purposes. Accreditation provides for evidence that a given organization meets given standards, while the EFQM model selects and awards organizations that have reached excellence in their sector or business (only winners are awarded) ${ }^{(20)}$. The EFQM may promote improvements, but through competitiveness rather than the development of organizational collaboration. Other studies state that the ISO, EFQM, and accreditation models are similar in the aspect of being based on reviewers' independence ${ }^{(5)}$.

The EFQM excellence model is considered to be generic enough to deal with health issues, but it does not cover all areas relevant to healthcare ${ }^{(26)}$. Integrating the EFQM self-evaluation method into accreditation may lead to excellence in healthcare. A barrier to the EFQM model's implementation relates to the terminology employed, because it originated in industry.

Recent studies have found that the healthcare excellence model covers all of the requirements of the JCI accreditation system ${ }^{(7)}$. The JCI is more comprehensive regarding the "process" criteria and sub-criteria of the EFQM model than regarding the "result" criteria. On the other hand, the JCI rules provide for excellence standards in healthcare services delivered that are internationally recognized and accepted. Models can be implemented in separate and supplementary ways. Other authors have also found that the accreditation model (the Iranian National Program for Hospital Evaluation [INPHE]) and the EFQM model present different results. This difference could be related to the EFQM performance criteria ${ }^{(8)}$.

A study studied the drivers and challenges posed to health organizations to implement quality initiatives ${ }^{(28)}$. According to the researcher, accreditation has an advantage over excellence models, because the first is focused on specific needs. However, excellence models are better at promoting a culture of quality and permanent improvement.

The authors performed a study of quality management systems development in Hungarian hospitals ${ }^{(35)}$. The study considered two certifications: ISO and the Hungarian Hospital Care Standards, which has a manual developed based on the JCI standards. The research result showed that the quality management system presents weak links between quality and safety, and certifications are not significantly related to the patient safety. On the one hand, the link between quality and safety supports the idea that patient safety should be incorporated into quality management systems. On the other hand, because this is quite a weak link, it supports the approach adopted by several countries that manage patient safety as a separate policy. This study also evaluated the patients' involvement in the process.

Although literature comparing both focuses is limited, the bibliographic research performed showed that the focuses of accreditation and of the EFQM management excellence model converge towards process improvement, higher patient satisfaction, and a search for organizational excellence. Among the main differences, it is worth mentioning that accreditation results in a certificate to successful organizations, while in the EFQM model the result is self-evaluation or a prize in acknowledgement of best organizations. Moreover, the accreditation process has standards, procedures, and language that are more deterministic and specifically oriented to the healthcare sector, 
while the EFQM model is more comprehensive in terms of economic activities and places more emphasis on the achievements and financial aspects of organizations.

\section{Characterization of Healthcare Organizations Studied}

Altogether, 11 hospitals and one clinical analysis laboratory participated in this study. Organizations were selected based on the criteria of a non-random sample, and can be considered as a sample for convenience. Table 1 shows the characteristics of the 12 participating organizations, which are all located in the state of São Paulo.

Table 1 - Organizations' characteristics - São Paulo, São Paulo, Brazil, 2015.

\begin{tabular}{|c|c|c|c|c|c|c|}
\hline & \multicolumn{2}{|c|}{ Accredited } & \multicolumn{2}{|c|}{ Non-accredited } & \multicolumn{2}{|r|}{ Total } \\
\hline & $\mathbf{N}$ & $\%$ & $\mathbf{N}$ & $\%$ & $\mathbf{N}$ & $\%$ \\
\hline \multicolumn{7}{|l|}{$\begin{array}{l}\text { Education } \\
\text { Institution }\end{array}$} \\
\hline Yes & 3 & $33.3 \%$ & 1 & $33.3 \%$ & 4 & $33.3 \%$ \\
\hline No & 6 & $66.7 \%$ & 2 & $66.7 \%$ & 8 & $66.7 \%$ \\
\hline \multicolumn{7}{|l|}{ Sector } \\
\hline Public & 5 & $55.6 \%$ & 2 & $66.7 \%$ & 7 & $58.3 \%$ \\
\hline Private & 4 & $44.4 \%$ & 1 & $33.3 \%$ & 5 & $41.7 \%$ \\
\hline \multicolumn{7}{|l|}{$\begin{array}{l}\text { Number of } \\
\text { Beds }\end{array}$} \\
\hline$<60$ & 0 & $0.0 \%$ & 1 & $33.3 \%$ & 1 & $8.3 \%$ \\
\hline $100-400$ & 6 & $66.7 \%$ & 0 & $0.0 \%$ & 6 & $50.0 \%$ \\
\hline $410-600$ & 3 & $33.3 \%$ & 1 & $33.3 \%$ & 4 & $33.3 \%$ \\
\hline$>700$ & 0 & $0.0 \%$ & 1 & $33.3 \%$ & 1 & $8.3 \%$ \\
\hline
\end{tabular}

Among the nine accredited organizations, eight are hospitals, of which five hold ONA national accreditation, one has an international accreditation (JCI), and two have both national accreditation (ONA) and international (one with JCI and another CCHSA). The laboratory assessed is accredited by the Clinical Laboratories Accreditation Program (Programa de Acreditação de Laboratórios Clínicos [PALC]), which is a national accreditation program created in 1988 by the Brazilian Association of Clinical Pathology/ Laboratorial Medicine (Sociedade Brasileira de Patologia Clinica/Medicina Laboratorial [SBPC/ML]).

In the 11 organizations, respondents to the self-evaluation questionnaire were responsible for their organizations' quality management systems. In one organization the questionnaire was jointly responded to by the administrative area and a functional area, because there was no area specifically centralizing quality management.

\section{Result of the Study of Multiple Cases}

Table 2 shows the total score of organizations in the self-evaluation stage, as well as the scores of the Facilitator and Results criteria according to the status concerning accreditation. To safeguard the institutions' confidentiality these were identified by numbers from 1 to 12 .
Table 2 - Results of the EFQM evaluation and accreditation status by Organization - São Paulo, São Paulo, Brazil, 2015.

\begin{tabular}{|c|c|c|c|}
\hline \multirow{2}{*}{ Organization } & \multicolumn{3}{|c|}{ EFQM Self-evaluation } \\
\hline & Facilitators $^{\mathrm{a}}$ & Results $^{b}$ & Total \\
\hline \multicolumn{4}{|l|}{ Accredited } \\
\hline ORG_01 & 387.6 & 393.2 & 780.9 \\
\hline ORG_02 & 432.5 & 380.3 & 812.9 \\
\hline ORG_03 & 444.3 & 432.2 & 876.5 \\
\hline ORG_04 & 394.6 & 380.2 & 774.8 \\
\hline ORG_05 & 403.1 & 375.8 & 778.9 \\
\hline ORG_06 & 364.9 & 336.9 & 701.8 \\
\hline ORG_07 & 243.2 & 236.6 & 479.7 \\
\hline ORG_08 & 277.7 & 321.8 & 599.5 \\
\hline ORG_09 & 391.3 & 243.5 & 634.8 \\
\hline Mean & 371.0 & 344.5 & 715.5 \\
\hline Minimum & 243.2 & 236.6 & 479.7 \\
\hline Maximum & 444.3 & 432.2 & 876.5 \\
\hline Standard deviation & 67.6 & 67.1 & 124.0 \\
\hline \multicolumn{4}{|l|}{ Non-accredited } \\
\hline ORG_10 & 162.9 & 100.8 & 263.7 \\
\hline ORG_11 & 246.7 & 152.9 & 399.6 \\
\hline ORG_12 & 188.5 & 122.9 & 311.4 \\
\hline Mean & 199.3 & 125.6 & 324.9 \\
\hline Minimum & 162.9 & 100.8 & 263.7 \\
\hline Maximum & 246.7 & 152.9 & 399.6 \\
\hline Standard deviation & 42.9 & 26.2 & 68.9 \\
\hline
\end{tabular}

Note: ${ }^{\mathrm{T}}$ The grade for Facilitators ranges from 0 to 500 points and considers the total score for the five categories Leadership; People; Policy and Strategy; Partnership and Resources; and Processes.

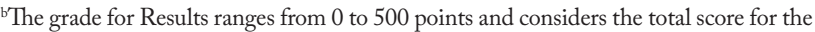
four categories People Results; Customer Results; Society Results; and Key Results.

Table 3 shows the result of the three survey hypotheses, pointing to the existence of statistical evidence, with $99 \%$ confidence, that the mean score of the Facilitators, Results, and Total for accredited organizations is higher than that for non-accredited organizations.

Table 3 - Result of the hypotheses test through means comparison (one-sided test with $99 \%$ of confidence) - São Paulo, São Paulo, Brazil, 2015.

\begin{tabular}{lcccc}
\hline Hypothesis & $\begin{array}{c}\text { Difference } \\
\text { between } \\
\text { means }^{\mathbf{a}}\end{array}$ & $\begin{array}{c}\text { Lower limit of } \\
\text { the difference }\end{array}$ & $\mathbf{t}$ & P value \\
\hline H01: Facilitators & 171.7 & 54.8 & 4.06 & 0.001 \\
H02: Results & 218.9 & 106.2 & 5.37 & 0.000 \\
H03: Total Score & 390.6 & 178.5 & 5.09 & 0.000 \\
\hline
\end{tabular}

Note: ${ }^{2}$ The difference is equal to the mean accredited organizations less the mean of non-accredited ones. 


\section{DISCUSSION}

The result of accredited organizations in self-evaluation, using a model based on EFQM, was better both in total score and sub-total for the categories of Facilitators and Results when compared against non-accredited organizations. Evaluating the score of sub-totals by category, we find the highest difference in the category of Results, corroborating indications obtained by the literature review, except for the study carried out in $\operatorname{Iran}^{(8)}$, where the average score in the EFQM model was lower than the score obtained in the evaluation using the national accreditation model. Previous studies ${ }^{(1,5,7,20-24)}$ comparing accreditation with the EFQM model showed convergence of both focuses.

Among the factors that collaborate to improve quality, the implementation of largely used tools like processes standardization, risks management, continuous improvement, and strategic planning is worth mentioning, among others.

In the literature the main impacts of accreditation were process standardization, conformity with external programs, organizational culture contributing to quality and safety, activities for continuous quality improvement, and leadership ${ }^{(9)}$. Other recent studies considered accreditation as a good investment because of its effect on strengthening both quality and safety culture ${ }^{(36)}$ and as the initial step in the process to reach excellence in hospitals ${ }^{(37)}$.

Moreover, it is worth keeping in mind that accreditation results in a quality seal or certificate that allows the institution's acknowledgment by the society and that may even be of international level. This is not true for the EFQM, which only awards organizations that reach excellence in their sectors.

Despite the convergence found between the two models, accreditation and EFQM, and although accreditation is the main model used by institutions in Brazil, it is worth considering that some studies describe that, in conceptual terms, the EFQM is the most complete model for the organization to reach quality goals because it provides a broader structure ${ }^{(22,24-25)}$. In this sense, the EFQM model or similar models of excellence might serve as a strategy for accredited organizations to seek continued improvement. In addition, being accredited before using the EFQM model could reduce the impact of the barrier created by terminology ${ }^{(26)}$, because teams would have had contact with many quality tools.

It is worth mentioning the limitations imposed by the methodological options of this survey. The first refers to the study of multiple cases, notably the sample size, selection of organizations, and application of questionnaires based on self-evaluation. The sample can be considered as a sample of convenience mainly due to the possibility of performing the study. Another limitation of the study is the difficulty of isolating only the accreditation impact on the comparative analysis with the EFQM model because of the dynamic of the process to improve organizations. In addition, there is a limitation regarding the initial sample extracted from international (Web of Science and MEDLINE) and national (USP Portal de Busca Integrada) databases, and because it considers only peer-reviewed articles. However, the initial sample was expanded through the network of articles chosen for reference that assisted the identification of two articles for the final article database.

\section{CONCLUSION}

The result of this survey suggests that accreditation, although focused on clinical aspects, leads health organizations to implement good quality management practices in line with those of other economic sectors.

The practical implication of this survey for health organizations is the selection of a quality model to be implemented. Understanding the models and their differences could contribute to the process of deciding which model should be implemented according to the short-, medium-, and long-term objectives of each organization.

\section{RESUMO}

Objetivo: Avaliar se as organizações de saúde acreditadas possuem melhores práticas de gestão do que as não acreditadas. Método: A pesquisa foi dividida em duas etapas: revisão da literatura e estudo de casos múltiplos com 12 organizações de saúde, localizadas no estado de São Paulo - Brasil. Foram pesquisados artigos que comparavam a acreditação hospitalar com o modelo de excelência em gestão da EFQM (European Foundation for Quality Management), sendo que a literatura pertinente considera que o modelo de acreditação e o modelo da EFQM são convergentes e, ao mesmo tempo, complementares em determinados aspectos. Resultados: Com 99\% de confiança, pode-se afirmar que há evidência de que as organizações com acreditação obtiveram uma pontuação maior na avaliação baseada no modelo EFQM comparativamente às organizações não acreditadas. Este resultado também se confirmou na comparação dos resultados das categorias Facilitadores e Resultados do modelo EFQM. Conclusão: Há uma convergência entre o modelo de acreditação e o modelo de excelência da EFQM, sugerindo que a acreditação contribui para o setor de saúde implementar as melhores práticas de gestão já difundidas em outros setores de negócio.

\section{DESCRITORES}

Acreditação; Hospitais; Administração Hospitalar; Gestão da Qualidade; Avaliação em Saúde.

\section{RESUMEN}

Objetivo: Evaluar si la organizaciones sanitarias acreditadas tienen mejores prácticas de gestión que las no acreditadas. Método: La investigación fue dividida en dos etapas: revisión de la literatura y estudio de casos múltiples con 12 organizaciones sanitarias, ubicadas 
en el Estado de São Paulo - Brasil. Fueron investigados artículos que comparaban la acreditación hospitalaria con el modelo de excelencia en gestión de la EFQM (European Foundation for Quality Management), siendo que la literatura pertinente considera que el modelo de acreditación y el modelo de la EFQM son convergentes y, a la vez, complementarios en determinados aspectos. Resultados: Con el 99\% de confianza, se puede afirmar que existe evidencia de que las organizaciones con acreditación obtuvieron una puntuación mayor en la evaluación basada en el modelo EFQM comparativamente con las organizaciones no acreditadas. Dicho resultado también se confirmó en la comparación de los resultados de las categorías Facilitadores y Resultados del modelo EFQM. Conclusión: Existe una convergencia entre el modelo de acreditación y el modelo de excelencia de la EFQM, sugiriendo que la acreditación contribuye a que el sector de salud implemente las mejores prácticas de gestión ya difundidas en otros sectores de negocio.

\section{DESCRIPTORES}

Acreditación; Hospitales; Administración Hospitalaria; Gestión de la Calidad; Evaluación en Salud.

\section{REFERENCES}

1. Shaw CD. External quality mechanisms for health care: summary of the ExPeRT project on visitatie, accreditation, EFQM and ISO assessment in European Union countries. External Peer Review Techniques. European Foundation for Quality Management. International Organization for Standardization. Int J Qual Heal Care. 2000;12(3):169-75.

2. Brasil. Lei n. 8.080, de 19 de setembro de 1990. Dispõe sobre as condições para a promoção, proteção e recuperação da saúde, a organização e o funcionamento dos serviços correspondentes e dá outras providências [Internet]. Brasília; 1990 [citado 2013 jan. 13]. Disponível em: http://www.planalto.gov.br/ccivil_03/leis/L8080.htm

3. Brasil. Projeto de Lei n 5.503, de 2013. Acrescenta o art. 39-A, à Lei no 8.080, de 19 de setembro de 1990 (Lei Orgânica da Saúde), para dispor sobre a obrigatoriedade de avaliação e certificação da qualidade dos serviços hospitalares [Internet]. Brasília; 1990 [citado 2013 jan. 13]. Disponível em: http://www.camara.gov.br/proposicoesWeb/prop_mostrarintegra;jsessionid=AD5D23A811DE960064EF5F0EC8 DFA3CC.proposicoesWeb1?codteor=1192872\&filename=Tramitacao-PL+5503/2013

4. Malik AM. O caminho da acreditação no país [opinião]. Rev Melhores Práticas. 2014;15(1):20-1.

5. Goldschmidt H, van der Weide W, van Gennip E. Application of the NIAZ frame of reference; impact on a departmental level. Accred Qual Assur. 2001;6:431-4.

6. Sangüesa M, Mateo R, Ilzarbe L. How hospitals choose a quality management system: relevant criteria in large spanish hospitals. Total Qual Manag Bus Excell. 2007;18(6):613-30.

7. Yousefian S, Harat AT, Fathi M, Ravand M. A proposed adaptation of joint commission international accreditation standards for hospital-$\mathrm{JCl}$ to the health care excellence model. Adv Environ Biol. 2013;7(6):956-67.

8. Imani Nasab MH, Mohaghegh B, Khalesi N, Jaafaripooyan E. Parallel quality assessment of emergency departments by european foundation for quality management model and iranian national program for hospital evaluation. Iran J Public Health. 2013;42(6):610-9.

9. Hinchcliff R, Greenfield D, Moldovan M, Westbrook JI, Pawsey M, Mumford V, et al. Narrative synthesis of health service accreditation literature. BMJ Qual Saf. 2012;21(12):979-91.

10. Mumford V, Forde K, Greenfield D, Hinchcliff R, Braithwaite J. Health services accreditation: what is the evidence that the benefits justify the costs? Int J Qual Heal Care. 2013;25(5):606-20.

11. Yepes-Baldó M, Romeo M, Berger R. Human capital questionnaire: assessment of European nurses' perceptions as indicators of human capital quality. Nurs Health Sci. 2013;15(2):229-34.

12. Siverbo K, Eriksson H, Raharjo H, Moonen M. Attitudes toward quality improvement among healthcare professionals: Lessons from a hospital-wide quality initiative. Int J Qual Serv Sci. 2014;6(2/3):203-12.

13. Matthies-Baraibar C, Arcelay-Salazar A, Cantero-González D, Colina-Alonso A, García-Urbaneja M, González-Llinares RM, et al. Is organizational progress in the EFQM model related to employee satisfaction? BMC Health Serv Res. 2014;14:468.

14. Moreno-Rodríguez JM, Cabrerizo FJ, Pérez IJ, Martínez MA. A consensus support model based on linguistic information for the initial-self assessment of the EFQM in health care organizations. Expert Syst Appl. 2013;40(8):2792-8.

15. Vallejo P, Saura RM, Sunol R, Kazandjian V, Ureña V, Mauri J. A proposed adaptation of the EFQM fundamental concepts of excellence to health care based on the PATH framework. Int J Qual Heal Care. 2006;18(5):327-35.

16. Pilkington A, Chai K-H. Research themes, concepts and relationships: a study of International Journal of Service Industry Management (1990-2005). Int J Serv Ind Manag. 2008;19(1):83-110.

17. Schildt H. SITKIS: software for bibliometric data management and analysis. Helsinki: Institute of Strategy and International Business; 2002.

18. Borgatti S, Everett M, Freeman L. Ucinet for Windows: software for social network analysis. Lexington, KY: Analytic Technologies; 2002.

19. Sweeney J, Heaton C. Interpretations and variations of ISO 9000 in acute health care. Int J Qual Heal Care. 2000;12(3):203-9.

20. Bohigas L, Heaton C. Methods for external evaluation of health care institutions. Int J Qual Heal Care. 2000;12(3):231-8.

21. Heaton C. External peer review in Europe: an overview from the ExPeRT Project. Int J Qual Heal Care. 2000;12(3):177-82.

22. Nabitz UW, Klazinga NS. EFQM approach and the Dutch Quality Award. Int J Health Care Qual Assur. 1999;12(3):65-70.

23. Donahue KT, van Ostenberg P. Joint Commission International accreditation: relationship to four models of evaluation. Int J Qual Heal Care. 2000;12(3):243-6.

24. Klazinga NS. Re-engineering trust: the adoption and adaption of four models for external quality assurance of health care services in western European health care systems. Int J Qual Heal Care. 2000;12(3):183-9. 
25. Nabitz U, Klazinga N, Walburg J. The EFQM excellence model: European and Dutch experiences with the EFQM approach in health care. Int J Qual Heal Care. 2000;12(3):191-201.

26. Moeller J. The EFQM Excellence Model: German experiences with the EFQM approach in health care. Int J Qual Heal Care. 2001;13(1):45-9.

27. Shaw C. External assessment of health care. BMJ. 2001;322(7290):851-4.

28. Abdallah A. Implementing quality initiatives in healthcare organizations: drivers and challenges. Int J Health Care Qual Assur. 2014;27(3):166-81.

29. European Foundation for Quality Management. Introducing the EFQM excellence model [Internet]. 2010 [cited 2013 Jan 13 ]. Available from: www.efqm.orgen/PdfResources/EFQMModel_Presentation.pdf

30. Favaretti C, De Pieri P, Torri E, Guarrera G, Fontana F, Debiasi F, et al. An EFQM excellence model for integrated healthcare governance. Int J Health Care Qual Assur. 2014;28(2):156-72.

31. Wagner C, Groene O, Thompson CA, Klazinga NS, Dersarkissian M, Arah OA, et al. Development and validation of an index to assess hospital quality management systems. Int J Qual Heal Care. 2014;26 S1:16-26.

32. Costa Neto PLO. Estatística. $3^{a}$ ed. São Paulo: Blücher; 2002.

33. Minitab 17 Statistical Software. State College, PA: Minitab; 2010.

34. Roberts JS, Coale JG, Redman RR. A history of the Joint Commission on Accreditation of Hospitals. JAMA. 1987;258(7):936-40.

35. Makai P, Klazinga N, Wagner C, Boncz I, Gulacsi L. Quality management and patient safety: Survey results from 102 Hungarian hospitals. Health Policy (New York). 2009;90(2-3):175-80.

36. Saleh SS, Sleiman JB, Dagher D, Sbeit H, Natafgi N. Accreditation of hospitals in Lebanon: is it a worthy investment? Int J Qual Heal Care. 2013;25(3):284-90.

37. Abdallah A, Haddadin BM, Al-Atiyat HM, Haddad LJ, Al-Sharif SL. Investigating the Applicability of EFQM and KAIIAE in Jordanian Healthcare Organizations: a case study. Jordan J Mech Ind Eng. 2013;7(1):49-55.

Financial Support: Coordenação de Aperfeiçoamento de Pessoal de Nível Superior - CAPES.

Acknowledgments: To the Production Engineering of the Escola Politécnica at

USP (Class of 2012) for their support in this research project. 